\title{
A novel mechanism for acquired cisplatin-resistance: Suppressed translation of death-associated protein kinase mRNA is insensitive to 5-aza-2'-deoxycitidine and trichostatin in cisplatin-resistant cervical squamous cancer cells
}

\author{
TAO BAI ${ }^{1}$, TETSUJI TANAKA ${ }^{1}$, KAZUNORI YUKAWA $^{2}$ and NAOHIKO UMESAKI ${ }^{1}$ \\ Departments of ${ }^{1}$ Obstetrics and Gynecology, ${ }^{2}$ Physiology, Wakayama Medical University, \\ 811-1 Kimi-idera, Wakayama 641-0012, Japan
}

Received August 12, 2005; Accepted September 29, 2005

\begin{abstract}
The molecular mechanism for cisplatin (CDDP)resistance of cancer cells has not yet been clarified, despite extensive studies. Here, we investigated whether deathassociated protein (DAP) kinase, an apoptosis modulator, was involved in CDDP-resistance by examining the ME180 human cervical squamous cancer cell line and 6 monoclonal ME180-derived CDDP-resistant subclones. Co-treatment with CDDP and 5-aza-2'-deoxycytidine (5-aza-CdR), a demethylating agent, significantly enhanced the CDDPsensitivities of the parent cells and CDDP-resistant subclones. Subsequent removal of 5-aza-CdR rapidly reversed the CDDP-sensitivity of the CDDP-resistant subclones to their original levels, whereas the parent cells retained the enhanced CDDP-sensitivity for at least $24 \mathrm{~h}$. Quantitative RT-PCR revealed that the CDDP-resistant subclones expressed higher DNA methyltransferase (DNMT) mRNA levels than the parent cells, suggesting that increased DNMT expressions easily restored the CDDP-resistance of the CDDP-resistant subclones following 5-aza-CdR removal. Although the parent cells showed hypermethylation in the DAP kinase promoter region, corresponding methylated bands were not detected in 2 of the 6 CDDP-resistant subclones by methylation-specific PCR. All 6 CDDP-resistant subclones expressed higher DAP kinase mRNA levels than the parent cells, as evaluated by quantitative RT-PCR. Although DAP kinase protein expression was strongly suppressed in the parent cells and CDDP-resistant subclones, 5-aza-CdR treatment of the parent cells dosedependently stimulated the DAP kinase protein expression, and this was synergistically enhanced by inhibiting histone
\end{abstract}

Correspondence to: Dr Tetsuji Tanaka, Department of Obstetrics and Gynecology, Wakayama Medical University, 811-1 Kimi-idera, Wakayama 641-0012, Japan

E-mail: tetanaka@wakayama-med.ac.jp

Key words: death-associated protein kinase, cisplatin-resistance, methylation, squamous cell carcinoma, cervical cancer deacetylation via trichostatin treatment in addition to 5-aza$\mathrm{CdR}$. However, DAP kinase protein expression in the CDDPresistant subclones was not stimulated by treatment with 5aza-CdR and/or trichostatin. These results indicate that posttranscriptional translation of DAP kinase mRNA is strongly suppressed and insensitive to treatment with 5-aza-CdR and trichostatin in the CDDP-resistant subclones established from ME180 human cervical squamous cancer cells. This CDDPresistance is accompanied by molecular changes that disturb the post-transcriptional translation of the DAP kinase mRNA, and these molecular changes are transiently restored by demethylation.

\section{Introduction}

Combination chemotherapy remains the predominant treatment approach before and after surgery for advanced malignant tumors although both de novo and acquired anticancer drug-resistance limits further treatment clinically. Among the important chemotherapeutic agents, cisplatin (CDDP) is particularly effective and clinically useful against various types of malignant tumor $(1,2)$. The ability of CDDP to become incorporated into DNA, where it forms intra- and inter-strand crosslinks, is generally considered to be one of its main anticancer effects $(3,4)$. However, a variety of observations reported for certain tumor types and cell lines suggest that the mechanism of CDDP-resistance is multifactorial, and involves alterations in drug-uptake and -efflux, defective mismatch repair due to hypermethylation of the human mut-L homologue 1 (hMLH1) gene promoter $(5,6)$, p53 mutations $(7,8)$, elevated cellular glutathione (GSH) levels and a concomitant increase of multidrug resistance protein 2 (MRP2) expression (9). Based on these potential mechanisms, a variety of approaches have been adopted to reverse or overcome CDDP-resistance, including demethylation (6). 5-aza-2'-deoxycytidine (5-aza-CdR), a demethylating agent, has been shown to induce demethylation by inhibiting DNA methyltransferases (DNMTs) and synergistically potentiating the cytotoxicity of CDDP due to DNA topologic changes $(10,11)$. It was reported that treatment of ovarian and colon carcinoma xenografts with 5 -aza-CdR and CDDP in vivo 
could reverse drug-resistance by restoring hMLH1 expression, which is silenced by promoter methylation (6). 5-aza-CdR inhibits DNA methylation by reducing DNMT enzymatic activity via stable complex formation between the enzyme and 5-aza-CdR-substituted DNA (12). In addition to DNA methylation, histone deacetylation is also involved in methylation-induced gene silencing (13). Furthermore, inhibition of histone deacetylation was reported to act synergistically with inhibition of DNA methylation to induce gene expression (14).

Death-associated protein (DAP) kinase is a cytoskeletonlocalized $\mathrm{Ca}^{2+} /$ calmodulin (CaM)-regulated serine/threonine kinase which modulates the cell death induced by interferon$\gamma$, tumor necrosis factor- $\beta$, Fas, transforming growth factor- $\beta$, the oncogenes c-myc and E2F, ceramide and detachment from the extracellular matrix (15-20). Conversely, several lines of evidence have indicated that DAP kinase functions as an anti-apoptotic factor in cells under normal growth conditions, depending on the apoptotic stimuli $(21,22)$. Hypermethylation of normally unmethylated $\mathrm{CpG}$ islands in the promoter regions of many genes, including DAP kinase, during the development of various malignancies results in transcriptional inactivation and loss of protein expression, which serves as an alternative mechanism to genetic alterations (23-28). Our previous study revealed that DAP kinase expression was strongly reduced, possibly via aberrant methylation, in many ovarian and uterine carcinoma cell lines (29). Recently, we established 6 monoclonal CDDP-resistant subclones from a cervical squamous cell carcinoma cell line, ME180 (30), in order to investigate the molecular mechanisms of CDDP-resistance in cervical cancer and squamous cell carcinoma. In the present study, we examined the effects of 5-aza-CdR treatment on DAP kinase expression, DAP kinase promoter methylation status and the CDDP-sensitivity of the CDDP-resistant subclones in order to investigate the potential therapeutic applications of regulating the DAP kinase expression and CDDP-sensitivity of CDDPresistant cancers.

\section{Materials and methods}

Cell lines and culture. The human cervical squamous cell carcinoma cell line, ME180, was purchased from the JCRB Cell Bank (Japan Collection of Research Bioresources Cell Bank, Tokyo, Japan). All cells were cultured in OPTI-MEM (Invitrogen Corp., Carlsbad, CA, USA) supplemented with $5 \%$ fetal bovine serum (FCS; Equitech Bio Inc., Ingram, TX, USA), $100 \mathrm{U} / \mathrm{ml}$ penicillin (PC), $100 \mu \mathrm{g} / \mathrm{ml}$ streptomycin (SM) and $0.25 \mu \mathrm{g} / \mathrm{ml}$ fungizone (Invitrogen) in $5 \% \mathrm{CO}_{2} / 95 \%$ air at $37^{\circ} \mathrm{C}$.

Establishment of CDDP-resistant subclones from ME180 cells. To establish CDDP-resistant subclones, ME180 cells were cultured with various concentrations of CDDP (courtesy of Nihon-Kayaku Co. Ltd., Tokyo, Japan) for 3-5 weeks, and the surviving cells were collected. This collection procedure after CDDP exposure was repeated 4 times. Finally, 6 single cell-derived CDDP-resistant subclones, designated CDDPrA, CDDPrB, CDDPrC, CDDPrD, CDDPrE and CDDPrF, were established by the limiting dilution method. The monoclonality of each CDDP-resistant subclone was confirmed by chromosome analysis (data not shown). The establishment of these CDDP-resistant subclones took 1 year.

$C D D P$-sensitivity assay. Cell viability was assayed using a non-RI colorimetric assay kit (XTT; Boehringer-Mannheim, Mannheim, Germany). The inhibitory effects of CDDP on cell growth were assayed as follows. Cells in the log-phase were detached using $0.25 \%$ trypsin/1 mM EDTA (Invitrogen), and cultured overnight in 96 -well plates $\left(5 \times 10^{3}\right.$ cells/well). On day 2, various concentrations of CDDP were added to the cells. On day 4 , the numbers of viable cells were evaluated using the XTT kit and expressed as the percentage of viable cells $(\%)$ relative to the mean number of viable unstimulated cells. All experiments were performed 3 times to verify the results. The data are shown as the mean $\pm \mathrm{SD}$, and comparative data $(n=6)$ were analyzed by ANOVA.

DNA fragmentation assay. ME180 parent cells and CDDPresistant subclones in the log phase were detached using $0.25 \%$ trypsin/ $1 \mathrm{mM}$ EDTA, and then cultured overnight in culture dishes $\left(3 \times 10^{6}\right.$ cells/dish) containing OPTI-MEM/5\% FCS/PC/SM. On day 2, CDDP (final concentrations: 4 and $20 \mu \mathrm{g} / \mathrm{ml}$ ) was added to the cells. On day 4, genomic DNA was extracted from all cells, including the dead ones, using a SepaGene DNA extraction kit (Sankyo-Junyaku Co. Ltd., Tokyo, Japan) and treated with $100 \mu \mathrm{g} / \mathrm{ml}$ of RNase A (Sigma, St. Louis, MO, USA) in TE buffer (10 mM Tris, $\mathrm{pH} 8.0,2 \mathrm{mM}$ EDTA) for $90 \mathrm{~min}$ at $37^{\circ} \mathrm{C}$ to remove any contaminating RNA. Then, approximately $20 \mu \mathrm{g}$ of the genomic DNA isolated from $5 \times 10^{5}$ cells was electrophoresed in a $1.4 \%$ agarose gel at $50 \mathrm{~V}$ for approximately $2 \mathrm{~h}$, stained with $5 \mu \mathrm{g} / \mathrm{ml}$ of ethidium bromide and visualized by UV fluorescence.

Effects of the methyltransferase inhibitor, 5-aza-CdR, on the $C D D P$-sensitivity of the parent cells and CDDP-resistant subclones. Approximately $5 \times 10^{3}$ ME180 parent cells or ME180-derived CDDP-resistant subclones were seeded in $0.1 \mathrm{ml}$ OPTI-MEM in 96-well culture plates and incubated for $24 \mathrm{~h}$. The medium was then replaced with medium containing the designated concentrations of CDDP with or without $1 \mu \mathrm{M}$ 5-aza-CdR (Sigma) and the cells were incubated for a further $48 \mathrm{~h}$. Then, the viable cell numbers were determined using Cell Counting Kit (Dojindo Chemical Laboratory Co. Ltd., Tokyo, Japan) according to the manufacturer's instructions. The absorbance was measured at $450 \mathrm{~nm}$ using a 96-well plate reader (Dainihon-Seiyaku Co., Osaka Japan). The absorbance obtained from control cells without drug administration was set as $100 \%$ viability. All experiments were performed 3 times to verify the results. The data are shown as the mean $\pm \mathrm{SD}$, and comparative data $(n=4)$ were analyzed by ANOVA.

Effects of 5-aza-CdR pretreatment on the CDDP-sensitivity of the parent cells and CDDP-resistant subclones. To examine the effects of sequential administration of 5-aza-CdR and CDDP, $5 \times 10^{3}$ ME180 parent cells or ME180-derived CDDPresistant subclones were plated in $0.1 \mathrm{ml}$ OPTI-MEM in 96-well culture plates and incubated for $24 \mathrm{~h}$. Then, the cells were exposed to $1 \mu \mathrm{M} 5$-aza-CdR or left untreated for a further $24 \mathrm{~h}$, followed by treatment with the indicated 
Table I. Primer sequences for DAPK-MS-PCR analysis.

\begin{tabular}{llcr}
\hline PCR analysis & \multicolumn{1}{c}{ Primer sequence } & Amplicon size (bp) & Refs. \\
\hline Stage I PCR & $\begin{array}{l}\text { Forward 5'-GGTTGTTTCGGAGTGTGAGGAG-3' } \\
\text { Reverse 5'-GCTATCGAAAACCGACCATAAAC-3' }\end{array}$ & 209 & $(33)$ \\
Stage II PCR & & & $(33)$ \\
Unmethylation & $\begin{array}{l}\text { Forward 5'-GGAGGATAGTTGGATTGAGTTAATGTT-3' } \\
\text { Reverse 5'-CAAATCCCTCCCAAACACCAA-3' }\end{array}$ & 106 & $(33)$ \\
Methylation & $\begin{array}{l}\text { Forward 5'-ATAGTCGGATCGAGTTAACGTC-3' } \\
\text { Reverse 5'-AAAACTAACCGAAACGACGACG-3' }\end{array}$ & 153 & \\
& & & \\
\hline
\end{tabular}

concentrations of CDDP for $48 \mathrm{~h}$. Finally, the viable cell numbers were determined as described above. All experiments were performed 3 times to verify the results. The data are shown as the mean $\pm \mathrm{SD}$, and comparative data $(n=4)$ were analyzed by ANOVA.

Western blot analysis of DAP kinase protein expression. The ME180 parent cells and CDDP-resistant subclones were incubated with $1 \mu \mathrm{M} 5$-aza-CdR for $96 \mathrm{~h}$ and/or with $300 \mathrm{nM}$ trichostatin (TSA), a histone deacetylase inhibitor (WakoJunyaku Co. Ltd., Tokyo, Japan), for 48 h, after which they were harvested and lysed with $0.3 \mathrm{ml}$ lysis buffer (Sigma). For dose-dependency experiments, ME180 parent cells were treated with various concentrations of 5-aza-CdR $(0.5-10 \mu \mathrm{M})$ for $96 \mathrm{~h}$ and then lysed as described above. The protein contents of the cell lysates were quantified using a Coomassie Plus Protein assay (Pierce Biotechnology Inc., Rockford, IL, USA) and aliquots (25 $\mu \mathrm{g}$ total protein) were dissolved in Laemmli SDS-PAGE sample buffer prior to separation by $7.5 \%$ SDS-PAGE. The separated proteins were transferred to a polyvinylidene fluoride membrane (ATTO Corp., Tokyo, Japan) by using a wet transfer method. The membrane was blocked with $5 \%$ skim milk for $1 \mathrm{~h}$ at room temperature and subsequently incubated with a mouse monoclonal anti-human DAP kinase antibody (clone 55, 1:5000 dilution; Sigma) for $1 \mathrm{~h}$ at room temperature. After washing with TBS-T $(20 \mathrm{mM}$ Tris, $\mathrm{pH} 7.6,0.3 \mathrm{M} \mathrm{NaCl}, 0.1 \%$ Tween-20), the membrane was incubated with a horseradish peroxidase-conjugated rabbit anti-mouse secondary antibody (Sigma) for $1 \mathrm{~h}$ at room temperature. The bound antibodies were detected using an ECL plus kit (Amersham Pharmacia Biotech, Uppsala, Sweden) and the membrane was scanned using a Luminocapture (type AE6955; ATTO Corp.).

Genomic DNA extraction and bisulfite modification for $D A P$ kinase methylation-specific polymerase chain reaction (DAPK-MS-PCR). Genomic DNA was isolated from cultured cells using a SepaGene kit (Sanko-Junyaku Ltd.) according to the manufacturer's instructions. The DNA concentrations were calculated from the UV absorptions at 260 and $280 \mathrm{~nm}$. Genomic DNA was modified by chemical treatment with sodium bisulfite (Sigma) as described previously $(31,32)$. In this reaction, all unmethylated cytosines were converted to uracils, while methylated cytosines remained unaltered. Briefly, $2 \mu \mathrm{g} / 50 \mu 1$ of DNA was denatured by adding freshly prepared sodium hydroxide (final concentration: $0.3 \mathrm{M}$ ) and incubating the mixture for $20 \mathrm{~min}$ at $37^{\circ} \mathrm{C}$. Then, $30 \mu \mathrm{l}$ of freshly prepared $10 \mathrm{mM}$ hydroquinine (Sigma) and $520 \mu 1$ of $3 \mathrm{M}$ sodium bisulfite ( $\mathrm{pH}$ 5.0) were added to the DNA solutions, mixed and incubated for $16 \mathrm{~h}$ at $55^{\circ} \mathrm{C}$. The DNA samples were desalted using a Wizard DNA Clean-Up System (Promega Corp., Madison, WI, USA) according to the manufacturer's protocol, redissolved in $50 \mu \mathrm{l}$ of autoclaved distilled water, desulfonated with $0.3 \mathrm{M} \mathrm{NaOH}$ for $20 \mathrm{~min}$ at $37^{\circ} \mathrm{C}$ and precipitated with ethanol. The bisulfite-modified genomic DNA was resuspended in $20 \mu 1$ of autoclaved distilled water and either used immediately or stored at $-70^{\circ} \mathrm{C}$.

DAP kinase-methylation-specific polymerase chain reaction (DAPK-MS-PCR). DAPK-MS-PCR was performed as described previously (33). Briefly, the bisulfite-modified DNA was used as a template for stage I PCR amplification to generate a 209-bp fragment of the DAP kinase gene that included a portion of its $\mathrm{CpG}$-rich promoter region. The stage I PCR primers recognized the modified DNA but could not discriminate between methylated and unmethylated alleles. Stage I PCR amplification was carried out as follows: $95^{\circ} \mathrm{C}$ for $15 \mathrm{~min}$; 35 cycles of $94^{\circ} \mathrm{C}$ for $1 \mathrm{~min}$ for denaturation, $58^{\circ} \mathrm{C}$ for $150 \mathrm{sec}$ for annealing and $72^{\circ} \mathrm{C}$ for $150 \mathrm{sec}$ for extension; followed by a final extension at $72^{\circ} \mathrm{C}$ for $10 \mathrm{~min}$. The stage I PCR products were diluted 50 -fold, and $5 \mu 1$ was subjected to stage II PCR amplification using primers specifically designed for methylated or unmethylated DNA in the promoter region of the DAP kinase gene. The primers used for stage I and II PCR amplification are summarized in Table I. For stage II $\mathrm{PCR}$, the annealing temperature was increased to $65^{\circ} \mathrm{C}$ and the annealing time was reduced to $90 \mathrm{sec}$ for 40 cycles. Stage II PCR amplified 153-bp and 106-bp products from methylated and unmethylated DAP kinase genes, respectively. Finally, these PCR products were electrophoresed in a $2.0 \%$ agarose gel at $100 \mathrm{~V}$ for approximately $30-40 \mathrm{~min}$, and visualized by staining with $5 \mu \mathrm{g} / \mathrm{ml}$ ethidium bromide.

Reverse transcriptase-polymerase chain reaction ( $R T-P C R)$ and quantitative real-time RT-PCR of DAP kinase and DNMT genes. Total RNA was isolated from cultured cells using 
Table II. Primer sequences for RT-PCR and quantitative real-time RT-PCR analysis.

\begin{tabular}{llcc}
\hline Gene & \multicolumn{1}{c}{ Primer sequence } & Amplicon size (bp) & Refs. \\
\hline DAP kinase & $\begin{array}{l}\text { Forward 5'-TGGATCCACCAGCAAAGCAC-3' } \\
\text { Reverse 5'-GTGTTGGTTAGTGAGGTTTC-3' }\end{array}$ & 350 & $(34)$ \\
DNMT-1 & $\begin{array}{l}\text { Forward 5'-GTTCTTCCTCCTGGAGAATGTCA-3' } \\
\text { Reverse 5'-GGGCCACGCCGTACTG-3' }\end{array}$ & 138 \\
DNMT-3A & Forward 5'-CCTGTGGGAGCCTCAATGTTA-3' & & $(35)$ \\
& Reverse 5'-TTCTTGCAGTTTTGGCACATTC-3' & 72 & $(35)$ \\
DNMT-3B & Forward 5'-GACTCGAAGACGCACAGCTG-3' \\
B-actin & Reverse 5'-CTCGGTCTTTGCCGTTGTTATAG-3' & & \\
& Forward 5'-ATTGCCGACAGGATGCAGAA-3' & & Original \\
\hline
\end{tabular}

TRIzol reagent (Invitrogen) for RT-PCR and an RNeasy mini kit (Qiagen Inc., Valencia, CA, USA) for real-time RT-PCR. Aliquots containing $1 \mu \mathrm{g}$ of total RNA were pretreated with DNase I (Invitrogen) and then used for cDNA synthesis with a reverse transcriptase kit (Bio-Rad, Hercules, CA, USA) in a reaction volume of $20 \mu$ l. Each cDNA product was diluted to $100 \mu 1$. The PCR reaction mixture $(25 \mu 1)$ contained $5 \mu 1$ of diluted cDNA, $0.125 \mu 1$ Hotstart polymerase (Qiagen Inc.), $0.2 \mathrm{mM}$ dNTP, $1 \mathrm{xQ}$ solution and $0.5 \mu \mathrm{M}$ primers. The primers used for DAP kinase, DNMT 1, DNMT 3A and DNMT 3B are summarized in Table II. $B$-actin was used as a positive control for the mRNA amount. For RT-PCR, an initial hot start at $95^{\circ} \mathrm{C}$ for 15 min was followed by 35 amplification cycles $\left(30 \mathrm{sec}\right.$ at $94^{\circ} \mathrm{C}, 30 \mathrm{sec}$ at the annealing temperature and $60 \mathrm{sec}$ at $72^{\circ} \mathrm{C}$ ). The annealing temperatures were $55^{\circ} \mathrm{C}$ for DAP kinase and $60^{\circ} \mathrm{C}$ for DNMT 1 , DNMT $3 \mathrm{~A}$ and DNMT 3B. The PCR products were electrophoresed in a $1.5-2.0 \%$ agarose gel at $100 \mathrm{~V}$ for approximately $30-40 \mathrm{~min}$ and visualized by staining with $5 \mu \mathrm{g} / \mathrm{ml}$ ethidium bromide. Quantitative real-time RT-PCR was performed using an iCycler (Bio-Rad). The PCR reaction mixture $(25 \mu \mathrm{l})$ contained $2.5 \mu 1$ of diluted cDNA, $12.5 \mu 1$ of $\mathrm{iQ}^{\mathrm{TM}}$ SYBR-Green Supermix (Bio-Rad) and $0.5 \mu \mathrm{M}$ of the above-described primers. An initial hot start at $95^{\circ} \mathrm{C}$ for 3 min was followed by 40 cycles of amplification $\left(95^{\circ} \mathrm{C}\right.$ for $30 \mathrm{sec}, 55^{\circ} \mathrm{C}$ for $30 \mathrm{sec}$ and $72^{\circ} \mathrm{C}$ for $60 \mathrm{sec}$ ). The relative values of DAP kinase mRNA in the ME180 parent cells and CDDP-resistant subclones

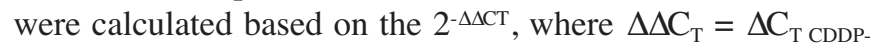
resistant subclones $-\Delta \mathrm{C}_{\mathrm{T} \text { ME180 parent cells }}=\left(\mathrm{C}_{\mathrm{T} \text { DAP kinase }}-\mathrm{C}_{\mathrm{T} \text { actin }}\right)_{\mathrm{CDDP} \text {-resistant }}$ subclones $-\left(\mathrm{C}_{\mathrm{T} \text { DAP kinase }}-\mathrm{C}_{\mathrm{T} \text { actin }}\right)_{\mathrm{ME} 180 \text { parent cells }}$.

\section{Results}

Establishment of 6 monoclonal CDDP-resistant subclones from the ME180 human cervical squamous cell carcinoma cell line. To investigate the mechanisms involved in anticancer drug-resistance, we established 6 independent monoclonal CDDP-resistant subclones from the ME180 cervical squamous cell carcinoma cell line using the limiting dilution method.
The CDDP-sensitivities of these subclones were determined using XTT assays. As shown in Fig. 1, all 6 CDDP-resistant subclones showed significantly lower CDDP-sensitivities than the parent cells. To confirm the resistance of the subclones against CDDP-induced apoptosis, we carried out DNA fragmentation assays. The parent cells and CDDP-resistant subclones were exposed to two different concentrations of CDDP (4 and $20 \mu \mathrm{g} / \mathrm{ml}$ ), based on the XTT assays shown in Fig. 1. After incubation with CDDP for $48 \mathrm{~h}$, DNA was extracted and chromatin fragmentation was examined by agarose gel electrophoresis. Typical DNA ladder patterns were detected in the parent cells treated with both 4 and $20 \mu \mathrm{g} / \mathrm{ml}$ CDDP, whereas DNA ladders were hardly seen in any CDDPresistant subclones examined after culture with $4 \mu \mathrm{g} / \mathrm{ml}$ of CDDP (Fig. 2).

Effects of demethylation on the CDDP-sensitivity of the $C D D P$-resistant subclones. To address whether the acquired CDDP-resistance of the 6 subclones was caused by aberrant methylation of gene promoters, we analyzed the effects of demethylation on the CDDP-sensitivity of the CDDP-resistant subclones (Fig. 3). Preliminary culture experiments with 5aza-CdR $(0-20 \mu \mathrm{M})$ treatment showed no growth-inhibitory effects on the ME180 parent cells (data not shown). Next, we treated the parent cells and CDDP-resistant subclones with various concentrations of CDDP and $10 \mu \mathrm{M} 5$-aza-CdR for $48 \mathrm{~h}$ to examine the effects of concurrent treatment with 5-aza$\mathrm{CdR}$ and CDDP on the CDDP-sensitivity. As shown in Fig. 3, parent cells co-treated with CDDP and 5-aza-CdR showed significantly increased CDDP-sensitivity compared to parent cells treated with CDDP alone. Among the 6 CDDP-resistant subclones, 3 subclones ( $\mathrm{B}, \mathrm{D}$ and $\mathrm{F}$ ) showed a much higher CDDP-sensitivity, while the other 3 subclones (A, C and E) showed a slightly, but significantly, higher CDDP-sensitivity when co-treated with CDDP and 5-aza-CdR compared with the same subclones treated with CDDP alone. To further elucidate the reversibility of the CDDP-sensitivity after demethylation in CDDP-resistant malignancies, we investigated the persistence of the demethylation-mediated sensitization 

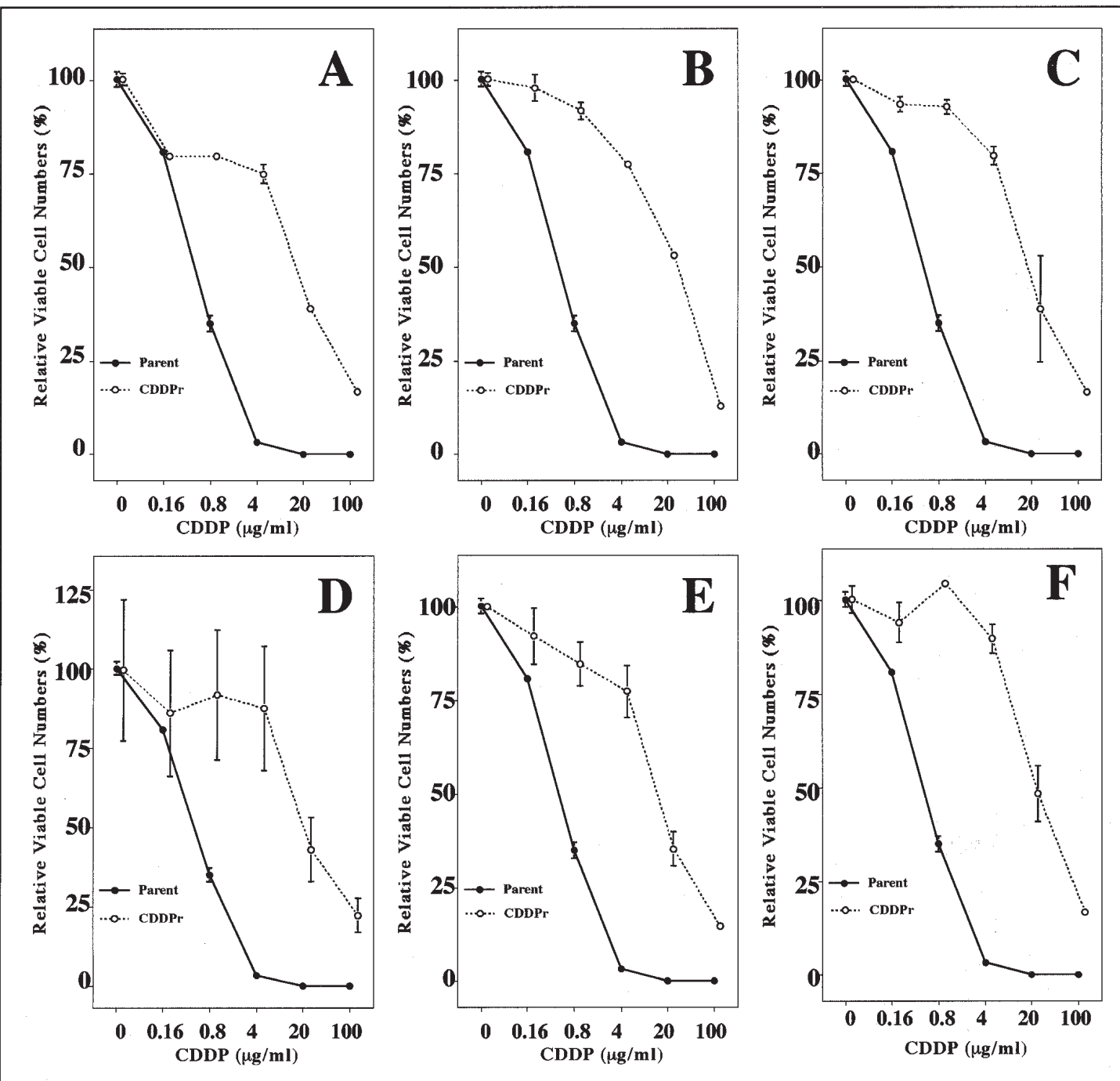

Figure 1. CDDP sensitivities of the CDDP-resistant subclones established from ME180 cells. Six monoclonal subclones (CDDPrA, B, C, D, E and F) were established. The solid lines with closed circles are CDDP-sensitivity curves of the parent cells and the dotted lines with open circles are CDDP-sensitivity curves of the CDDP-resistant subclones. All the subclones are clearly more resistant to CDDP-induced inhibition of cell growth than the parent cells.

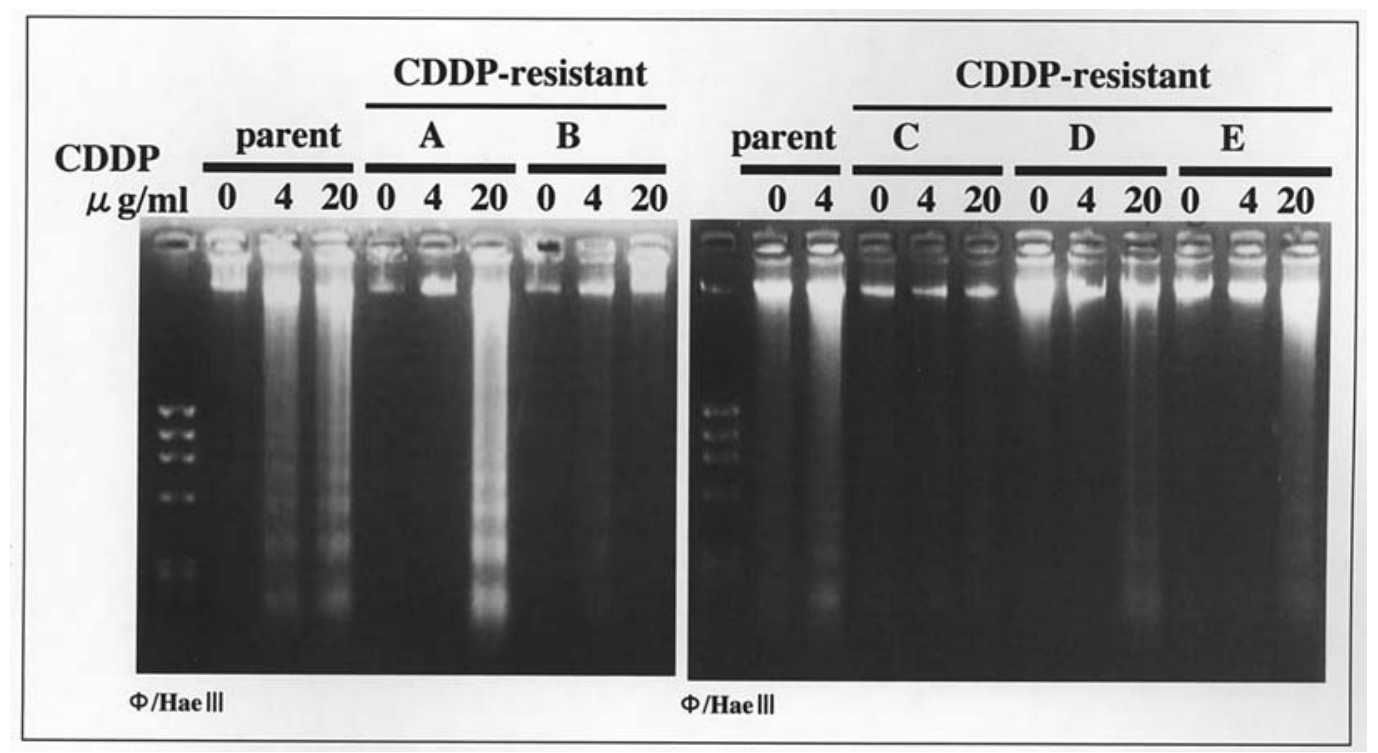

Figure 2. DNA fragmentation assay of the CDDP-resistant subclones. CDDP-induced DNA fragmentation is inhibited in the CDDP-resistant subclones (CDDPrA, B, C, D and E). 

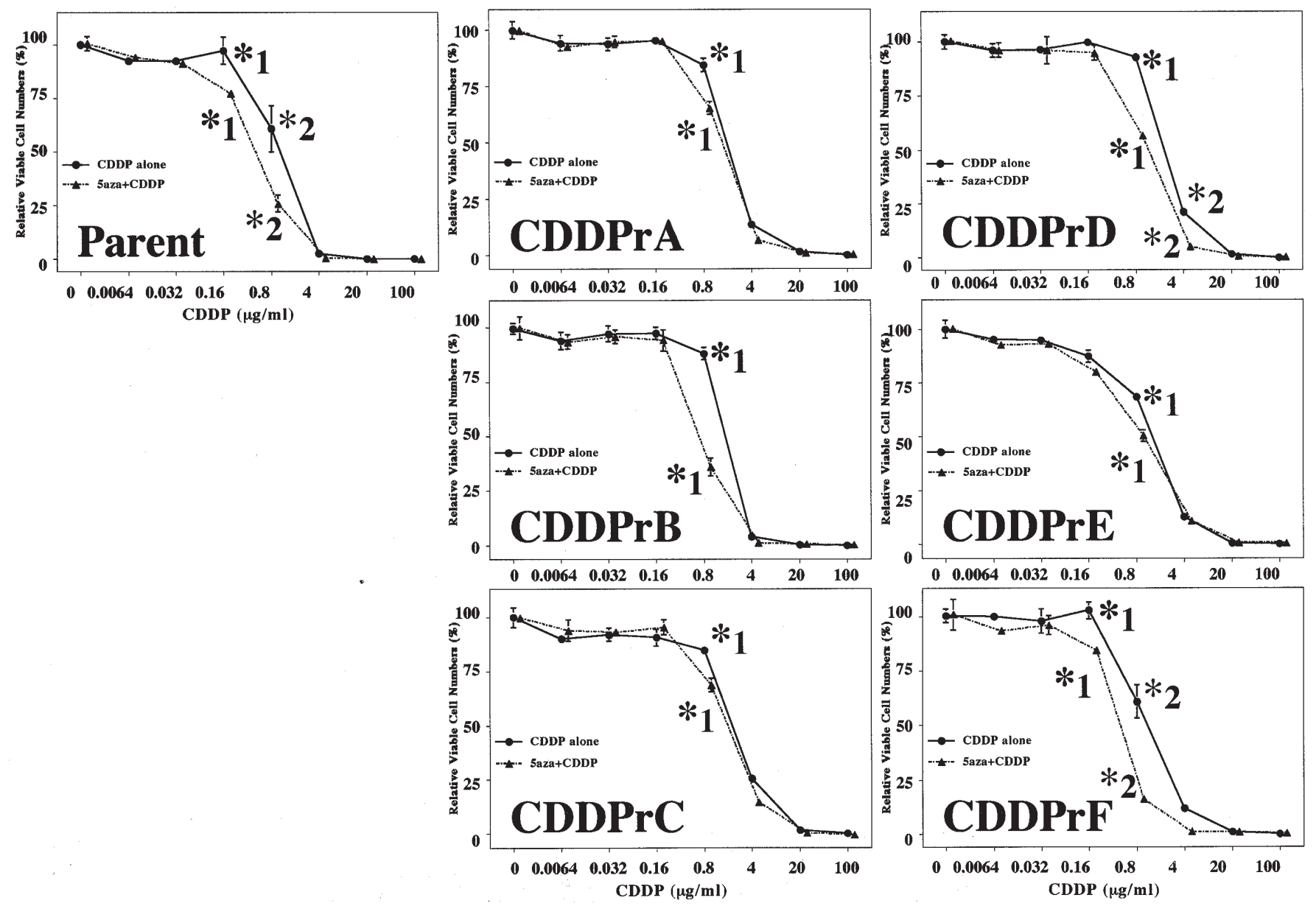

Figure 3. Effects of 5-aza-CdR treatment on the CDDP-sensitivities of the parent cells and CDDP-resistant subclones. The cells were concurrently treated with CDDP and 5-aza-CdR. The solid lines with closed circles are CDDP-sensitivity curves of cells without 5-aza-CdR treatment and the dotted lines with closed triangles are CDDP-sensitivity curves of cells treated with 5-aza-CdR. All the cells treated with 5-aza-CdR and CDDP show significantly higher CDDP-sensitivities than cells treated with CDDP alone. ${ }^{*} \mathrm{p}<0.05$.

to CDDP in the parent cells and CDDP-resistant subclones for $24 \mathrm{~h}$ after 5-aza-CdR-pretreatment (Fig. 4). The results showed that the parent ME180 cells retained the CDDPsensitivity restored by the 5 -aza-CdR treatment after its removal, whereas all the CDDP-resistant subclones lost their restored CDDP-sensitivity.

Increased expression of DNMT genes in CDDP-resistant subclones. Since the CDDP-resistant subclones failed to maintain their restored CDDP-sensitivity, we speculated that the status of the DNMTs in the CDDP-resistant subclones may be altered during exposure to CDDP. To clarify whether DNMT expression was up-regulated in CDDP-resistant subclones compared with parent ME180 cells, we assessed the transcriptional expression of DNMTs by RT-PCR and quantitative real-time RT-PCR. As shown in Fig. 5A, RT-PCR readily detected the expression of DNMT 1, DNMT 3A and DNMT 3B in parent ME180 cells and all CDDP-resistant subclones. Moreover, quantitative real-time RT-PCR revealed that 3 CDDP-resistant subclones (A, C and E) showed significantly higher DNMT 3B mRNA expression and slightly higher DNMT 1 mRNA expression than the parent cells. As shown in Fig. 3, these 3 subclones showed smaller increases in their cellular CDDP-sensitivity than the other subclones upon co-treatment with 5-aza-CdR and CDDP, suggesting that the increased DNMT 3B and DNMT 1 levels could inhibit the effects of 5-aza-CdR in these 3 subclones.

The methylation status of the DAP kinase promoter in CDDPresistant subclones. Several lines of evidence have shown that the hypermethylation of gene promoters is involved in drugresistance $(5,31,32)$. Previously, we reported that abnormal methylation of the DAP kinase gene promoter occurred and the level of DAP kinase protein was markedly diminished in the ME180 cell line (29). In view of the ability of DAP kinase to modulate apoptosis positively or negatively, depending on the cell type and apoptotic stimuli, we hypothesized that DAP kinase may be involved in anticancer drug-induced apoptosis and regulate the drug-sensitivity of malignant cells. Since the parent cells and CDDP-resistant subclones all showed increased CDDP-sensitivity upon co-treatment with CDDP and 5-aza$\mathrm{CdR}$, it is likely that the $\mathrm{CpG}$ island in the DAP kinase gene promoter is hypermethylated in CDDP-resistant subclones. To address this possibility, we examined the methylation status of the DAP kinase gene promoter using DAPK-MS-PCR (Fig. 6). In 2 of the 6 CDDP-resistant subclones ( $\mathrm{C}$ and $\mathrm{E}$ ), the band indicating hypermethylation of the DAP kinase gene promoter was not detected, while the others showed aberrant methylation. 

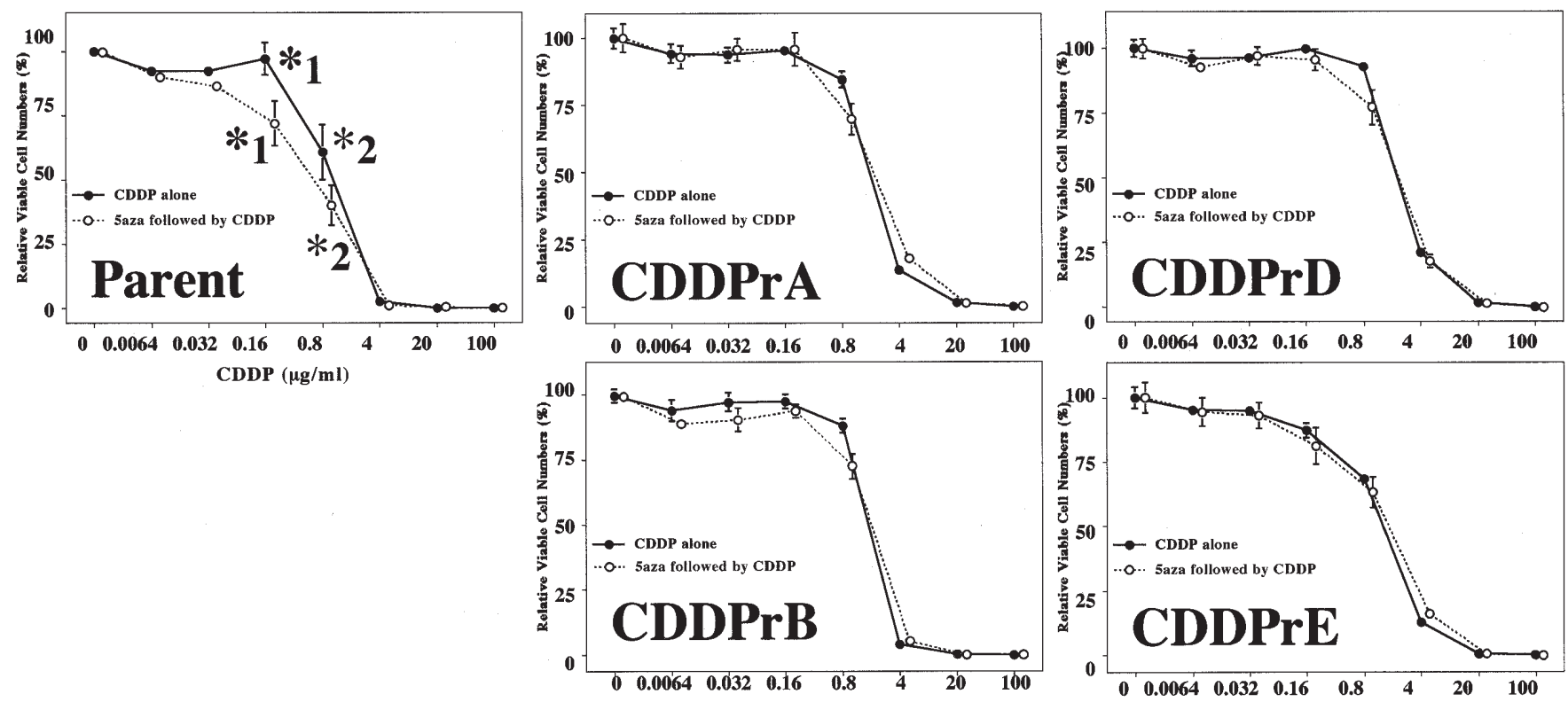

$\operatorname{CDDP}(\mu \mathrm{g} / \mathrm{ml})$
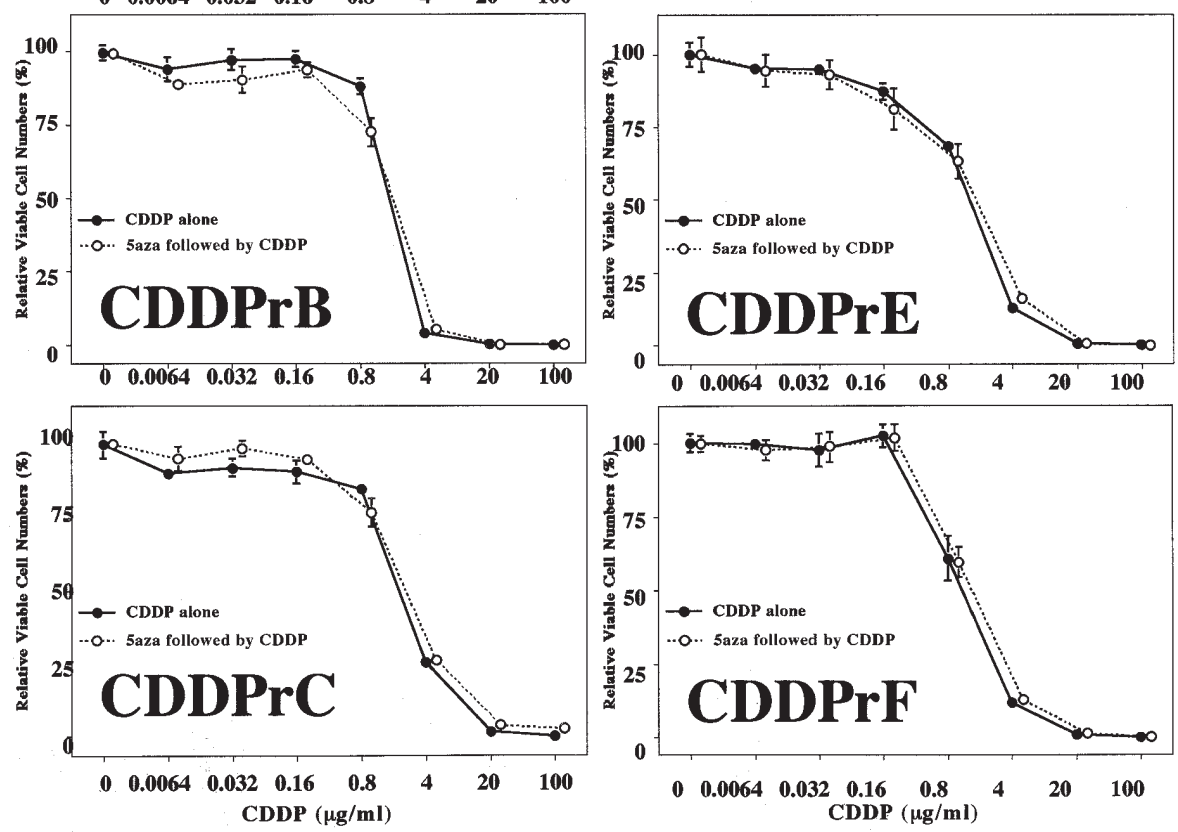

Figure 4. Effects of 5-aza-CdR removal on the CDDP-sensitivity of parent cells and CDDP-resistant subclones. The cells were stimulated with CDDP alone after pretreatment with 5-aza-CdR. The solid lines with closed circles are CDDP-sensitivity curves of cells treated with CDDP alone and the dotted lines with open circles are CDDP-sensitivity curves of cells treated with CDDP after 5-aza-CdR pretreatment. Although the parent cells exhibit a significantly higher CDDP-sensitivity after pretreatment with 5aza-CdR, all 6 CDDP-resistant subclones show no apparent changes in their CDDP-sensitivity with and without 5-aza-CdR pretreatment. ${ }^{*} \mathrm{p}<0.05$

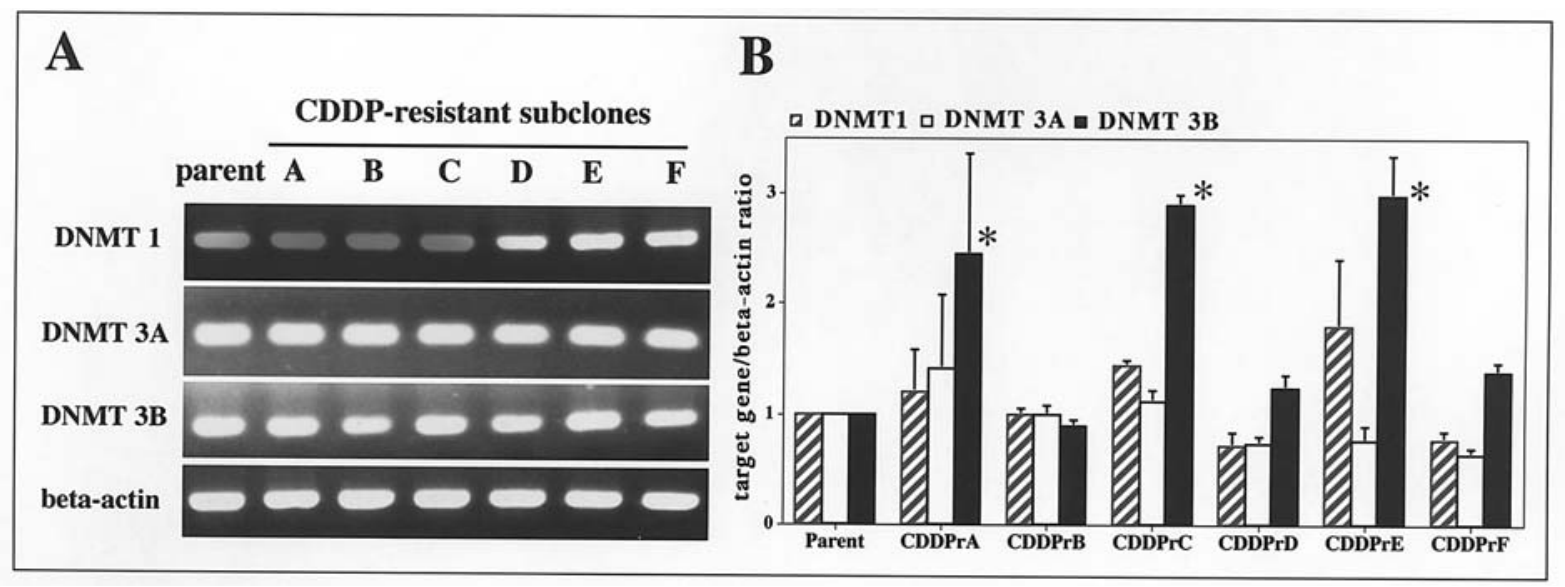

Figure 5. RT-PCR and quantitative real-time RT-PCR analyses of DNA methyltransferase mRNAs in CDDP-resistant subclones. A, RT-PCR analyses of DNA methyltransferase genes in CDDP-resistant subclones. Both the parent cells and CDDP-subclones express the 3 DNA methyltransferase mRNAs examined. B, Quantitative real-time RT-PCR analyses of 3 DNA methyltransferase genes: DNMT 1, DNMT 3A and DNMT 3B. "DNMT 3B mRNA expression is more than 2-fold higher in 3 CDDP-resistant subclones (CDDPrA, CDDPrC and CDDPrE) than in the parent cells. DNMT 1 mRNA expression is also slightly increased in these subclones, albeit to lesser extents.

The expression of DAP kinase protein in parent cells and CDDP-resistant subclones before and after treatment with 5-aza-CdR and/or TSA. Next, we examined the DAP kinase protein expression in parent cells and CDDP-resistant subclones by Western blot analysis. First, we investigated whether the DAP kinase protein expression in ME180 parent 


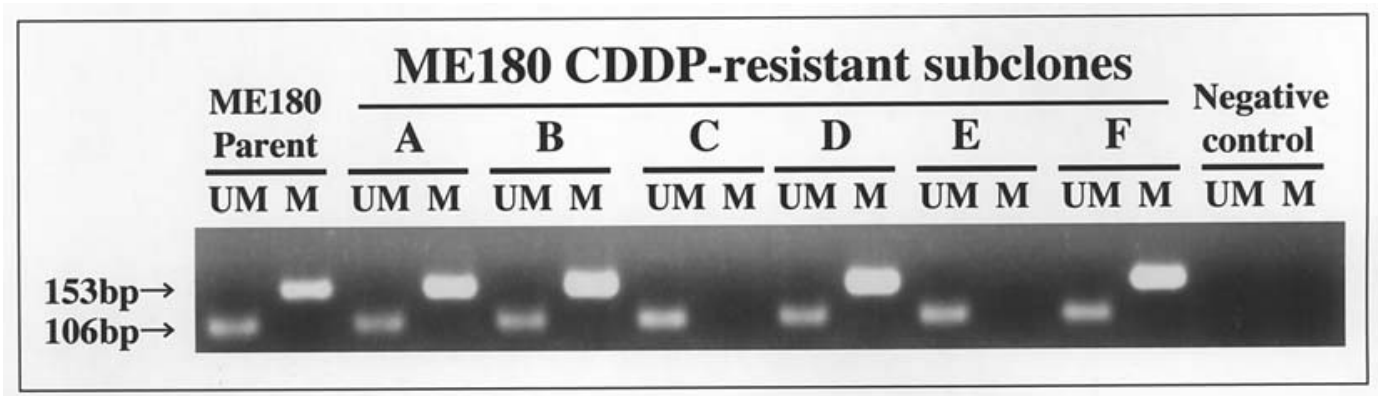

Figure 6. MS-DAPK-PCR analyses of CDDP-resistant subclones. Methylation-specific PCR of the DAP kinase gene was performed in ME180 parent cells and CDDP-resistant subclones. The parent cells have both the methylated and unmethylated bands. Two CDDP-resistant subclones (C and E) do not contain the methylated band. U, unmethylated; M, methylated.

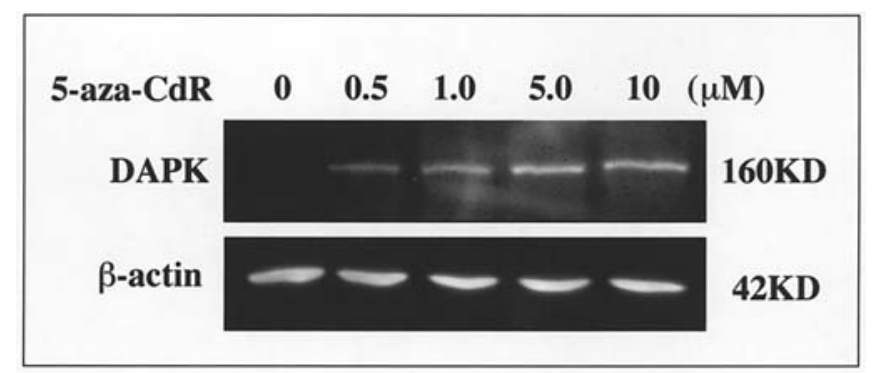

Figure 7. Effects of 5-aza-CdR treatment on DAP kinase protein expression in parent cells. The DAP kinase protein expression in parent ME180 cells is induced by 5 -aza-CdR treatment in a dose-dependent manner.

cells was regulated by 5 -aza-CdR treatment. In the parent cells, DAP kinase protein expression was remarkably suppressed. However, after treatment with various concentrations of 5aza-CdR $(0.5-10 \mu \mathrm{M})$ for $96 \mathrm{~h}$, the parent cells showed increased DAP kinase protein expression in a dose-dependent manner (Fig. 7).

Secondly, we examined the DAP kinase protein expression in parent cells and CDDP-resistant subclones before and after treatment with 5-aza-CdR and/or TSA. Similar to the case for the parent ME180 cells, 5 of the 6 CDDP-resistant subclones (A, B, C, D and F) showed slightly detectable DAP kinase protein expression (Fig. 8). Next, we treated the parent cells and CDDP-resistant subclones with $1 \mu \mathrm{M} 5$-aza-CdR and/or $300 \mathrm{nM}$ TSA, a histone deacetylase inhibitor (Fig. 8). In the parent cells, 5-aza-CdR treatment alone restored the expression of DAP kinase, and combined treatment of 5-aza-CdR and TSA caused a synergistic increase in DAP kinase protein expression. However, treatment of the parent cells with TSA alone induced little increase in the DAP kinase protein expression. In contrast to the parent cells, no distinguishable changes in DAP kinase protein expression were detected in any of the 6 CDDP-resistant subclones after treatment with 5-aza-CdR and/or TSA. These results demonstrated that the induction of DAP kinase protein expression was not responsible for the restoration of CDDP-sensitivity by 5 -aza-CdR treatment shown in Figs. 3 and 4, since DAP kinase protein expression was not enhanced by 5-aza-CdR treatment in CDDP-resistant subclones whose CDDP-sensitivity was restored by 5-azaCdR.
Transcription of the DAP kinase gene in parent cells and CDDP-resistant subclones. Although hypermethylation of the DAP kinase promoter was not detected in 2 of the 6 CDDP-resistant subclones by DAPK-MS-PCR, all 6 CDDPresistant subclones failed to recover DAP kinase protein expression in response to demethylation after 5-aza-CdR treatment, suggesting that defective DAP kinase gene transcription may occur in CDDP-resistant subclones. Therefore, RT-PCR analysis was performed to estimate the DAP kinase gene transcription in parent cells and CDDP-resistant subclones. As shown in Fig. 9A, all of the cells tested showed readily detectable DAP kinase mRNA expression by RT-PCR. Next, quantitative real-time RT-PCR was carried out to investigate the mRNA expression levels in the parent cells and CDDP-resistant subclones. As shown in Fig. 9B, all 6 CDDP-resistant subclones expressed significantly higher levels of DAP kinase mRNA than the parent cells. These results indicated that impaired translation of the DAP kinase mRNA, rather than transcriptional repression of the DAP kinase gene, strongly reduced the DAP kinase protein expression in CDDPresistant subclones.

\section{Discussion}

The epigenetic hypermethylation of gene promoters plays an important role in tumorigenesis as an alternative mechanism of genetic changes (36). The pattern of hypermethylation can be divided into age- or cancer-specific methylation $(37,38)$. On the other hand, CDDP-resistance is a multifactorial condition, which involves decreased drug-uptake, increased drug-efflux and increased intracellular GSH (39) as well as genetic and epigenetic alterations, such as p53 mutations and hMLH1 hypermethylation (7). Furthermore, CDDP-resistance has also been reported to be associated with reciprocal EGF receptor and p21 expression in ME180 cells (40). Here, we focused on DAP kinase, an apoptosis modulator that has been reported to show abnormal methylation in many tumor types, including cervical cancer $(25,41)$. We made several important observations regarding the relationship between DAP kinase expression and CDDP-resistance in the ME180 cervical squamous cell carcinoma cell line. To the best of our knowledge, this study represents the first report to investigate the relationships between CDDP-resistance and the regulatory system of DAP kinase expression. To evaluate the differing 


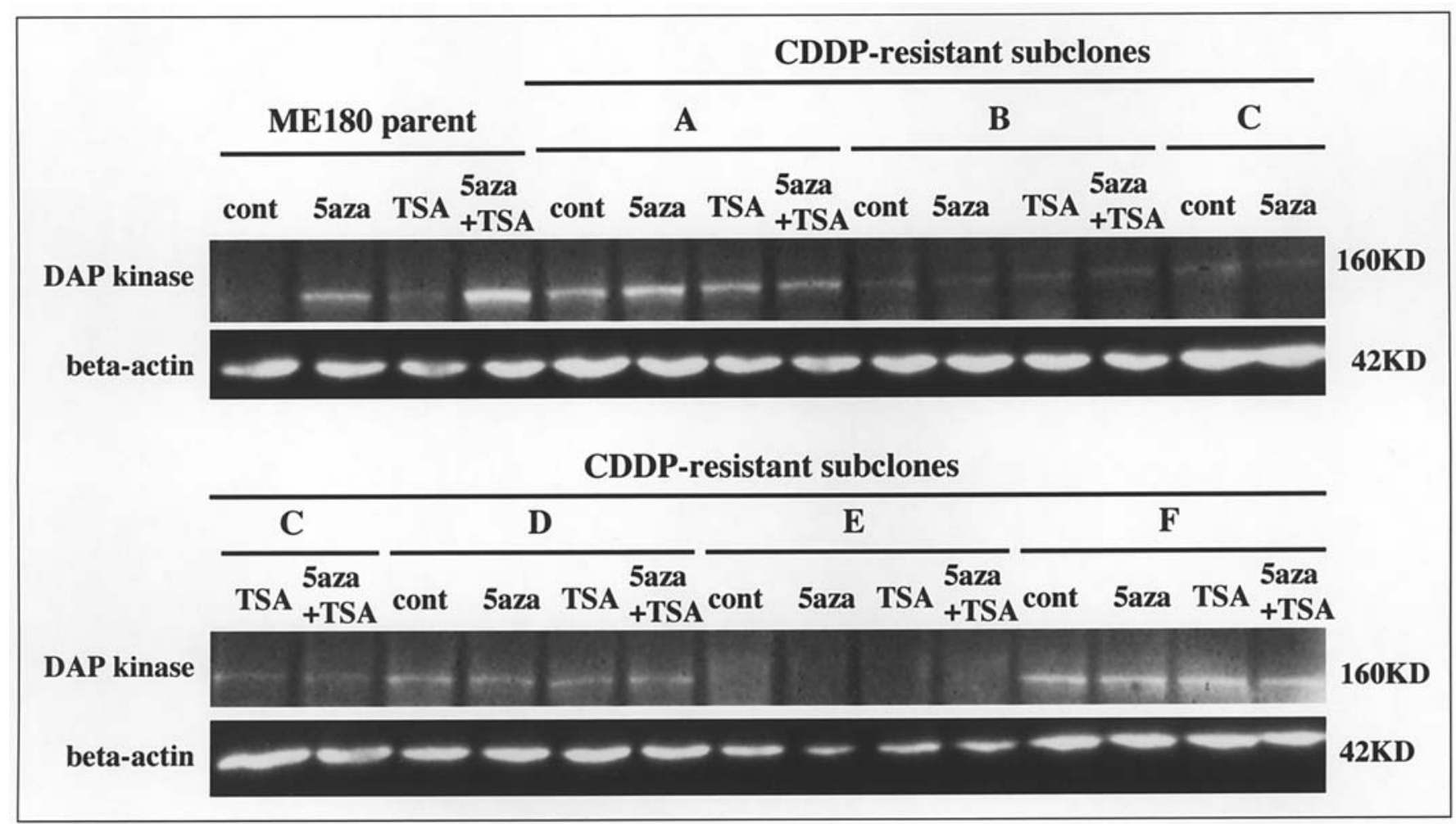

Figure 8. Effects of stimulation with 5-aza-CdR and/or TSA on DAP kinase protein expression in parent cells and CDDP-resistant subclones. Treatment with 5-aza-CdR clearly induces DAP kinase protein expression in parent cells. TSA synergistically enhances the DAP kinase protein expression induced by 5-aza-CdR in the parent cells. None of the CDDP-resistant subclones show induction of DAP kinase protein expression following treatment with 5-aza-CdR and/or TSA.

responsiveness to CDDP, we established 6 monoclonal CDDPresistant subclones from ME180 cells, and then examined the effects of CDDP in combination with the demethylating agent, 5-aza-CdR, or the sequential treatment with 5-aza-CdR and CDDP of parent cells and CDDP-resistant subclones. The CDDP-sensitivity of the parent cells and CDDP-resistant subclones was significantly enhanced by 5 -aza-CdR treatment, consistent with the previous finding that the cytotoxicity of a combination of CDDP and 5-aza-CdR against several tumor cell lines was synergistic (10). Based on the pattern of enhanced sensitivity to CDDP exposure after 5-aza-CdR treatment, the CDDP-resistant subclones were divided into two groups: one consisting of subclones B, D and F, which showed a relatively high responsiveness to 5 -aza-CdR treatment; and the other consisting of subclones A, C and E, with a comparatively low responsiveness. We speculated that differences in the DNMT levels among these CDDP-resistant subclones may be responsible for the differing responsiveness to 5-aza-CdR between the 2 groups. DNMT 3A and DNMT 3B are thought to be the major de novo methylases that affect the methylation status of normally unmethylated CpG sites (42-44). Furthermore, in vitro methylation assays have shown that DNMT 3A and DNMT 3B cooperate with DNMT 1 to extend methylation within the Micrococcus luteus genome (45). Therefore, it seems likely that the lower CDDP-sensitivities of subclones A, C and E compared with the other subclones upon co-treatment with 5-aza-CdR and CDDP is partly attributable to the enhanced expression of DNMT 1 and DNMT 3B. Collectively, these observations suggest the

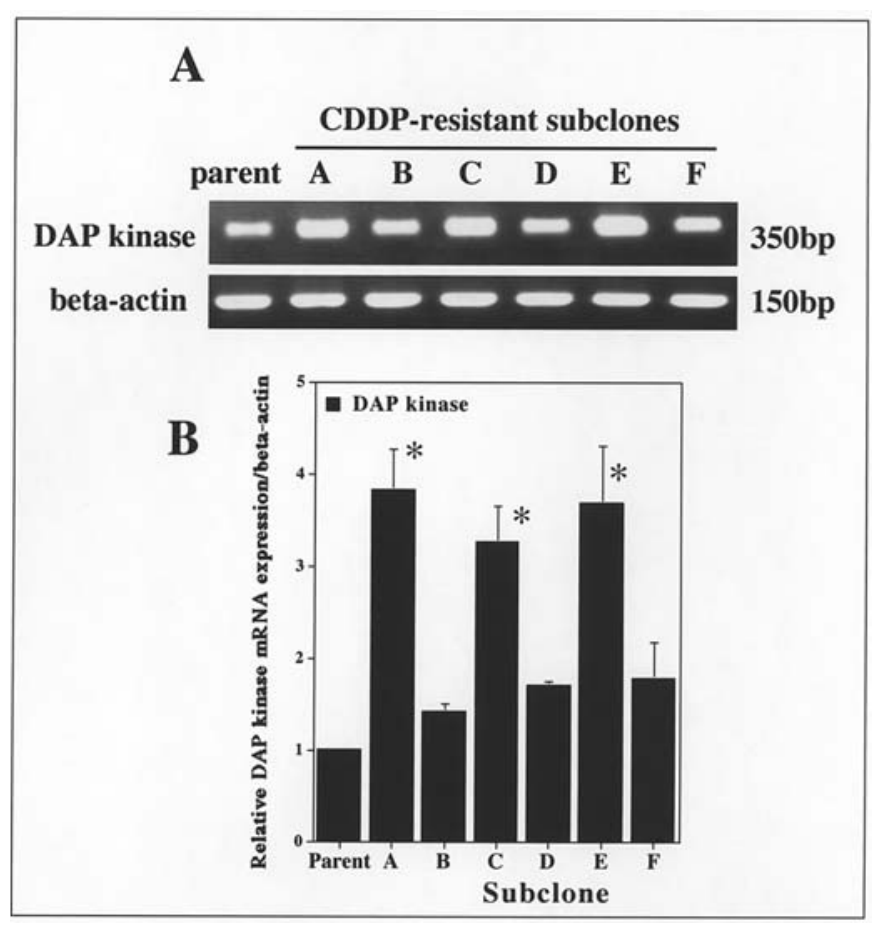

Figure 9. RT-PCR and quantitative real-time RT-PCR analyses of DAP kinase mRNA in CDDP-resistant subclones. A, RT-PCR analysis of CDDPresistant subclones. B, Quantitative real-time RT-PCR analysis of DAP kinase mRNA. All of the CDDP-resistant subclones express higher DAP kinase mRNA levels than the parent cells. *DAP kinase mRNA expression is more than 2-fold higher in 3 CDDP-resistant subclones (CDDPrA, CDDPrC and CDDPrE) than in the parent cells. 
possible application of a demethylating treatment, such as 5-aza-CdR, to cancer therapy, which could overcome acquired CDDP-resistance. In the present study, however, the CDDPsusceptibilities of the CDDP-resistant subclones rapidly returned to their original CDDP-sensitivity levels after the removal of 5-aza-CdR. Therefore, in order to overcome CDDP-resistance, long-acting demethylating drugs combined with CDDP may be essential for therapeutic use.

We also examined whether the CDDP-sensitivity of the parent cells and CDDP-resistant subclones correlated with the methylation status of the DAP kinase gene. Our previous study demonstrated that DAP kinase protein expression was strongly suppressed in ME180 cells, possibly due to aberrant methylation of the DAP kinase gene promoter (29). Thus, we examined the methylation status of the DAP kinase gene in CDDP-resistant subclones. We observed that the CDDP-resistant subclones showed little DAP kinase protein expression, similar to the ME180 parent cells. Interestingly, DAPK-MS-PCR was unable to detect a hypermethylated band in 2 of the 6 CDDP-resistant subclones (C and E), while hypermethylation of the DAP kinase promoter was easily detected in the other 4 CDDP-resistant subclones (A, B, D and F). A possible explanation is that our DAPK-MS-PCR is not sufficiently sensitive to identify the hypermethylation status of all of the targeted genes, and that undetected methylation sites are located in the DAP kinase promoter region in the 2 CDDP-resistant subclones (C and E). Further sequencing analyses of the full-length promoter region of the DAP kinase gene are necessary to verify this possibility. Alternatively, it is possible that these CDDP-resistant subclones isolated independently from the ME180 cell line may have diverged and acquired certain alterations during the selection cultures with CDDP. In addition, we noted that, even in the parent ME180 cells and 4 methylation-positive CDDPresistant subclones, the methylated bands were always accompanied by unmethylated bands, suggesting that the 2 methylation-negative CDDP-resistant subclones expressing normal unmethylated DAP kinase promoters may originate from ME180 clones that possessed the unmethylated allele of the DAP kinase gene. Quantitative RT-PCR revealed that all of the CDDP-resistant subclones showed higher DAP kinase mRNA expression levels than the parent cells. In particular, much higher DAP kinase mRNA expression levels were found in the 3 subclones (A, C and E) whose CDDP-sensitivity was less affected by 5 -aza-CdR than in the other 3 subclones (B, D and F). Since the 2 CDDP-resistant subclones without methylated bands in MS-DAPK-PCR (C and E) expressed much higher DAP kinase mRNA levels than the parent cells, DAP kinase mRNA transcription is partly regulated by methylation of the promoter region even in the CDDP-resistant subclones.

We then analyzed whether hypermethylation of the DAP kinase gene was sufficient to silence DAP kinase gene transcription and whether 5-aza-CdR-mediated demethylation affected the methylation status in the parent cells and CDDPresistant subclones. Unexpectedly, we noted that the reduced DAP kinase protein expression in ME180 cells did not result from silenced transcription of the DAP kinase gene by hypermethylation of the DAP kinase gene promoter $\mathrm{CpG}$ island. DAP kinase mRNA expression was easily detected in the parent cells and all of the CDDP-resistant subclones. Thus, the post-transcriptional translation of DAP kinase mRNA was strongly suppressed in the ME180 parent cells and CDDP-resistant subclones. A similar discrepancy between the mRNA expression level and amount of protein expression was previously reported for the transcriptional regulatory factor, PAX6, in the SW837 human colorectal carcinoma cell line (40). However, the expression of DAP kinase protein was recovered to detectable levels in the ME180 parent cells upon 5-aza-CdR treatment in a dose-dependent manner, suggesting that the post-transcriptionally suppressed DAP kinase protein expression was at least partially attributable to aberrant methylation. Treatment with TSA alone had little effect on the DAP kinase protein re-expression in parent ME180 cells. Furthermore, combined treatment with 5-azaCdR and TSA synergistically enhanced the DAP kinase protein expression in parent cells compared to treatment with 5-aza-CdR or TSA alone, consistent with a previous observation suggesting a more dominant role for methylation over histone deacetylase activity in mammals for the maintenance of gene silencing in association with $\mathrm{CpG}$ methylation (14). In contrast to the ME180 parent cells, 5 of the CDDP-resistant subclones (A, B, C, D and F) showed slightly detectable DAP kinase protein expression and all 6 retained DAP kinase mRNA expression. Moreover, quantitative RT-PCR analysis revealed that all 6 CDDP-resistant subclones had apparently higher DAP kinase mRNA expression levels than the parent cells. However, unlike the parent cells, all 6 CDDP-resistant subclones failed to show induction of DAP kinase protein expression upon treatment with 5-aza-CdR and/or TSA. Therefore, our results indicate that the acquired CDDP-resistance in the ME180-derived CDDP-resistant subclones is not caused directly by induction of DAP kinase protein expression. The impaired translation of DAP kinase mRNA after demethylation and/or inhibition of histone deacetylation was a common characteristic among all of the CDDP-resistant subclones. Thus, the acquisition of CDDPresistance may be caused by gene mutations that strongly interrupt the post-transcriptional modulation of DAP kinase mRNA and simultaneously reduce the CDDP-sensitivity.

Our present results revealed that treatment with 5-azaCdR could overcome CDDP-resistance in CDDP-resistant subclones established from the ME180 cervical carcinoma cell line, and that neither the methylation status of the DAP kinase promoter nor the DAP kinase protein expression level was directly involved in the acquisition of CDDP-resistance. CDDP-resistance may be caused by unknown molecular changes in the post-transcriptional mechanism that modulate the translation of DAP kinase mRNA. These currently unknown molecular changes in CDDP-resistant subclones are considered to be transiently restored by demethylation treatment. The present study is the first to demonstrate that the impaired translation mechanisms of DAP kinase mRNA are involved in the acquired CDDP-resistance of human cancer cells.

\section{Acknowledgments}

This study was supported in part by a Grant-in-Aid for Scientific Research from the Ministry of Education, 
Science, Sports and Culture of Japan and a Grant-in-Aid for Scientific Research from the Ministry of Welfare and Labor of Japan.

\section{References}

1. Giaccone G: Clinical perspective on platinum resistance. Drugs 59: 9-17, 2000.

2. Einhorn EH: Testicular cancer: an oncological success story. Clin Cancer Res 3: 2630-2632, 1997.

3. Pinto AL and Lippard SJ: Binding of the antitumor drug cisdiamminedichloroplatinum(II) (cisplatin) to DNA. Biochim Biophys Acta 780: 167-180, 1985.

4. Caradona JP, Lippard SJ, Gait MJ and Singh M: The antitumor drug cis-[ $\mathrm{Pt}(\mathrm{NH} 3) 2 \mathrm{Cl} 2]$ forms an intrastrand $\mathrm{d}(\mathrm{GpG})$ cross-link upon reaction with $[\mathrm{d}(\mathrm{ApGpGpCpCpT)}) 2$. J Am Chem Soc 104: 5793-5795, 1982

5. Brown R, Hirst GL, Gallagher WM, McIlwrath AJ, Margison GP, van der Zee AG and Anthoney DA: hMLH1 expression and cellular responses of ovarian tumour cells to treatment with cytotoxic anticancer agents. Oncogene 15: 45-52, 1997.

6. Plumb JA, Strathdee G, Sludden J, Kaye SB and Brown R: Reversal of drug resistance in human tumor xenografts by 2'deoxy-5-azacytidine-induced demethylation of the hMLH1 gene promoter. Cancer Res 60: 6039-6044, 2000.

7. Branch P, Masson M, Aquilina G, Bignami M and Karran P: Spontaneous development of drug resistance: mismatch repair and p53 defects in resistance to cisplatin in human tumor cells. Oncogene 19: 3138-3145, 2000.

8. Brown R, Clugston C, Burns P, Edlin A, Vasey P, Vojtesek B and Kaye SB: Increased accumulation of p53 protein in cisplatinresistant ovarian cell lines. Int J Cancer 55: 678-684, 1993.

9. Kool M, Haas M, Scheffer GL, Scheper RJ, Eijk, Juijn JA, Baas F and Borst P: Analysis of expression of cMOAT (MRP2), MRP3, MRP4, and MRP5, homologues of the multidrug resistance-associated protein gene (MRP1), in human cancer cell lines. Cancer Res 57: 3537-3547, 1997.

10. Frost P, Abbruzzese JL, Hunt B, Lee D and Ellis M: Synergistic cytotoxicity using 2'-deoxy-5-azacytidine and cisplatin or 4hydroperoxycyclophosphamide with human tumor cells. Cancer Res 50: 4572-4577, 1990.

11. Ellerhorst JA, Frost P, Abbruzzese JL, Newman RA and Chernajovsky Y: 2'-deoxy-5-azacytidine increases binding of cisplatin to DNA by a mechanism independent of DNA hypomethylation. Br J Cancer 67: 209-215, 1993.

12. Santi DV, Garrett CE and Barr PJ: On the mechanism of inhibition of DNA-cytosine methyltransferases by cytosine analogs. Cell 33: 9-10, 1983.

13. Nguyen CT, Gonzales FA and Jones PA: Altered chromatin structure associated with methylation-induced gene silencing in cancer cells: correlation of accessibility, methylation, MeCP2 binding and acetylation. Nucleic Acids Res 29: 4598-4606, 2001.

14. Cameron EE, Bachman KE, Myöhänen S, Herman JG and Baylin SB: Synergy of demethylation and histone deacetylase inhibition in the re-expression of genes silenced in cancer. Nat Gene 21: 103-107, 1999.

15. Cohen O, Inbal B, Kissil JL, Raveh T, Berissi H, SpivakKroizaman T, Feinstein E and Kimchi A: DAP kinase participates in TNF-alpha- and Fas-induced apoptosis and its function requires the death domain. J Cell Biol 146: 141-148, 1999.

16. Jang CW, Chen CH, Chen CC, Chen JY, Su YH and Chen RH: TGFB induces apoptosis through Smad-mediated expression of DAP kinase. Nat Cell Biol 4: 51-58, 2002.

17. Raveh T, Droguett G, Horwitz MS, De Pinho RA and Kimchi A: DAP kinase activates a p19ARF/p53-mediated apoptotic checkpoint to suppress oncogenic transformation. Nat Cell Biol 3: $1-7,2001$

18. Pelled D, Raveh T, Riebeling C, Fridkin M, Berissi H, Futerman AH and Kimchi A: Death-associated protein (DAP) kinase plays a central role in ceramide induced apoptosis in cultured hippocampal neurons. J Biol Chem 277: 1957-1961, 2002.

19. Yamamoto M, Hioki T, Nakajima-Iijima $S$ and Uchino S: DAP kinase activity is critical for C (2)-ceramide-induced apoptosis in PC12 cells. Eur J Biochem 269: 139-147, 2002.

20. Wang WJ, Kuo JC, Yao CC and Chen RH: DAP kinase induces apoptosis by suppressing integrin activity and disrupting matrix survival signals. J Cell Biol 159: 169-179, 2002.
21. Jin Y, Blue EK, Dixon S, Hou L, Wysolmerski RB and Gallagher PJ: Identification of a new form of death-associated protein kinase that promotes cell survival. J Biol Chem 276: 39667-39678, 2001.

22. Jin Y and Gallagher PJ: Antisense depletion of death-associated protein kinase promotes apoptosis. J Biol Chem 278: 51587-51593, 2003.

23. Lee TL, Leung WK, Chan MW, Ng EK, Tong JH, Lo KW, Chung SC, Sung JJ and To KF: Detection of gene promoter hypermethylation in the tumor and serum of patients with gastric carcinoma. Clin Cancer Res 8: 1761-1766, 2002.

24. Chan MW, Chan LW, Tang NL, Tong JH, Lo KW, Lee TL, Cheung HY, Wong WS, Chan PS, Lai Fm and To KF: Hypermethylation of multiple genes in tumor tissues and voided urine in urinary bladder cancer patients. Clin Cancer Res 8: 464-470, 2002.

25. Dong SM, Kim HS, Rha SH and Sidransky D: Promoter hypermethylation of multiple genes in carcinoma of the uterine cervix. Clin Cancer Res 7: 1982-1986, 2001.

26. Kim DH, Nelson HH, Wiencke JK, Christiani DC, Wain JC, Mark EJ and Kelsey KT: Promoter methylation of DAP-kinase: association with advanced stage in non-small cell lung cancer. Oncogene 20: 1765-1770, 2000 .

27. Sanchez-Cespedes M, Esteller M, Wu L, Nawroz-Danish H, Yoo GH, Koch WM, Jen J, Herman JG and Sidransky D: Gene promoter hypermethylation in tumors and serum of head and neck cancer patients. Cancer Res 60: 892-895, 2000.

28. Katzenellenbogen RA, Baylin SB and Herman JG: Hypermethylation of the DAP-kinase $\mathrm{CpG}$ island is a common alteration in B-cell malignancies. Blood 93: 4347-4353, 1999.

29. Bai T, Tanaka T, Yukawa K, Maeda M and Umesaki N: Reduced expression of death-associated protein kinase in human uterine and ovarian carcinoma cells. Oncol Rep 11: 661-665, 2004.

30. Lancillotti F, Giandomenico V, Affabris E, Fiorucci G, Romeo $G$ and Rossi GB: Interferon alpha-2b and retinoic acid combined treatment affects proliferation and gene expression of human cervical carcinoma cells. Cancer Res 55: 3158-3164, 1995.

31. Mackay HJ, Cameron D, Rahilly M, Mackean MJ, Paul J, Kaye SB and Brown R: Reduced MLH1 expression in breast tumors after primary chemotherapy predicts disease-free survival. J Clin Oncol 18: 87-93, 2000.

32. Strathdee G, MacKean MJ III and Mand Brown R: A role for methylation of the hMLH1 promoter in loss of hMLH1 expression and drug resistance in ovarian cancer. Oncogene 18: 2335-2341, 1999.

33. Koul S, McKiernan JM, Narayan G, Houldsworth J, Bacik J, Dobrzynski DL, Assaad AM, Mansukhani M, Reuter VE, Bosl GJ, Chaganti RS and Murty VV: Role of promoter hypermethylation in Cisplatin treatment response of male germ cell tumors. Mol Cancer 3: 16, 2004.

34. Yukawa K, Shirasawa N, Ohshima A, Mune M, Kimura A, Bai T, Tsubota Y, Owada-Makabe K, Tanaka T, Kishino M, Tsuruo Y, Umesaki N and Maeda M: Death-associated protein kinase localization to human renal tubule cells, and increased expression of chronic obstructive uropathy in rats. J Nephrol 17: 26-33, 2004

35. Li S, Chiang TC, Richard-Davis G, Barrett JC and Mclachlan JA: DNA hypomethylation and imbalanced expression of DNA methyltransferases (DNMT1, 3A, and 3B) in human uterine leiomyoma. Gynecol Oncol 90: 123-130, 2003.

36. Jones PA and Baylin SB: The fundamental role of epigenetic events in cancer. Nat Rev Genet 3: 415-428, 2002.

37. Toyota M, Ahuja N, Ohe-Toyota M, Herman JG, Baylin B and Issa JP: CpG island methylator phenotype in colorectal cancer. Proc Natl Acad Sci USA 96: 8681-8686, 1999.

38. Toyota M, Ahuja N, Suzuki H, Itoh F, Ohe-Toyota M, Imai M, Baylin SB and Issa JP: Aberrant methylation in gastric cancer associated with the $\mathrm{CpG}$ island methylator phenotype. Cancer Res 59: 5438-5442, 1999

39. Godwin AK, Meister A, O'Dwyer PJ, Huang CS, Hamilton TC and Anderson ME: High resistance to cisplatin in human ovarian cancer cell lines is associated with marked increase of glutathione synthesis. Proc Natl Acad Sci USA 89: 3070-3074, 1992.

40. Salem CE, Markl ID, Bender CM, Gonzales FA, Jones PA and Liang G: PAX6 methylation and ectopic expression in human tumor cells. Int J Cancer 87: 179-185, 2000. 
41. Narayan G, Arias-Pulido H, Koul S, Vargas H, Zhang FF, Villella J, Schneider A, Terry MB, Mansukhani M and Murty VV: Frequent promoter methylation of CDH1, DAPK, RARB, and HIC1 genes in carcinoma of cervix uteri: its relationship to clinical outcome. Mol Cancer 2: 24, 2003.

42. Bestor TH: Activation of mammalian DNA methyltransferase by cleavage of a $\mathrm{Zn}$ binding regulatory domain. EMBO J 11 : 2611-2617, 1992.

43. Robertson KD, Uzvolgyi E, Liang G, Talmadge C, Sumegi J, Gonzales FA and Jones PA: The human DNA methyltransferases (DNMTs) 1, 3a and 3b: coordinate mRNA expression in normal tissues and overexpression in tumors. Nucleic Acids Res 27: 2291-2298, 1999.
44. Okano M, Bell DW, Haber DA and Li E: DNA methyltransferases Dnmt 3a and Dnmt 3b are essential for de novo methylation and mammalian development. Cell 99: 247-257, 1999.

45. Kim GD, Ni J, Kelesoglu N, Roberts RJ and Pradhan S: Cooperation and communication between the human maintenance and de novo DNA (cytosine-5) methyltransferases. EMBO J 21: 4183-4195, 2002. 
